\title{
AUTONOMIA TRYBUNAŁÓW KOŚCIELNYCH W POLSCE W ORZEKANIU NIEWAŻNOŚCI MAŁŻEŃSTWA KANONICZNEGO: PRZYCZYNEK DO ANALIZY ZAGADNIENIA
}

Jedną z podstawowych kwestii prawa wyznaniowego jest analiza i regulacja relacji między państwem a poszczególnymi Kościołami i związkami wyznaniowymi istniejącymi na terytorium tegoż państwa. Oznacza to m.in. konieczność dookreślenia relacji między prawem państwowym a prawem rzeczonych wspólnot kościelnych, co ostatecznie prowadzi do wyznaczenia zakresu jurysdykcji państwa i Kościoła.

Już samo uznanie prawa kanonicznego za prawo jako takie oznacza świadomość, że determinuje ono właściwy mu obszar stanowienia norm prawnych, wprowadzanych w życie na tym samym terytorium, na którym państwo stanowi własne przepisy państwowego systemu prawnego. Następstwem takiego stanowiska jest z kolei założenie, że istnieją takie zakresy stosunków prawnych, które regulowane są zarówno przez prawo danego państwa, jak i prawo konkretnego Kościoła ${ }^{1}$. Nie jest to - zauważa M. Pietrzak - łatwy do rozwiązania problem, nie tyle z teoretycznego, co z praktycznego punktu widzenia ${ }^{2}$.

Ks. dr hab. Piotr Rygula, prof. UKSW - kierownik Katedry Prawa Wyznaniowego i Komparatystyki Prawniczej, Instytut Prawa Kanonicznego, Wydział Prawa Kanonicznego, Uniwersytet Kardynała Stefana Wyszyńskiego w Warszawie, ul. Dewajtis 5, 01-815 Warszawa; e-mail: p.rygula@ uksw.edu.pl; https://orcid.org/0000-0003-1716-2789

${ }^{1}$ A. RzEPECKI, Funkcjonowanie prawa kanonicznego w polskim porzadku prawnym - zarys tematu, „Acta Erasmiana” 5 (2013), s. 163-184.

2 M. Pietrzak, Prawo kanoniczne w polskim systemie prawnym, „Państwo i Prawo” 8 (2006), s. 16. Odnosząc się do powyższego stwierdzenia M. Pietrzaka dodam, że zagadnienie współistnienia i współobowiązywania wspomnianych wyżej praw nie należy do łatwych nie tylko z praktycznego punktu widzenia; także w teorii jest źródłem odmiennych nieraz opinii. Ze względu właśnie na tę różnorodność perspektyw i wyrażanych w doktrynie prawa wyznaniowego opinii, tak w Polsce, jak i w innych krajach, w tytule wskazuję, iż artykuł ten w zamierzeniu autora nie pretenduje do całościowej analizy zagadnienia. Stanowi przyczynek do istniejących już analiz we wspomnianym temacie. 
Wynikające stąd napięcie w przeszłości rozwiązywano odwołując się niejednokrotnie do rozróżnienia pomiędzy sprawami określanymi jako doczesne (podlegające władzy państwa), duchowe (podlegające władzy Kościoła) oraz mieszane ${ }^{3}$. Rozróżnienie to zakładało, że można w sposób racjonalny zakwalifikować do którejś z tych kategorii każdą poddającą się regulacji prawnej sprawę. Doświadczenie wskazuje jednak, że powyższe założenie, zastosowane w praktyce, nie zawsze niosło z sobą rozstrzygnięcia oceniane jako właściwe dla państwa czy Kościoła.

W związku z powyższym warto przytoczyć w tym miejscu opinię R. Sobańskiego, wyrażoną w referacie wygłoszonym na posiedzeniu Komitetu Nauk Prawnych PAN, w której to podkreślał, że „nie jakiś aprioryczny podział spraw wedle przedmiotu, lecz misja Kościoła respektowana na zasadzie wolności religijnej pozwala ustalić zasięg autonomicznego i niezależnego kościelnego porządku prawnego"4. W zgodzie z tą opinią wydaje się pozostawać art. 5 Konkordatu, w którym „Państwo zapewnia Kościołowi Katolickiemu [...] swobodne i publiczne pełnienie jego misji, łącznie z wykonywaniem jurysdykcji [...] na podstawie prawa kanonicznego"5. W takim ujęciu misja Kościoła Katolickiego staje się wyznacznikiem gwarantowanego przez Państwo zakresu swobodnego, publicznego działania tego Kościoła.

Pisząc o rozgraniczeniu porządków prawnych trzeba wspomnieć o teorii recepcji prawa wewnętrznego Kościołów i związków wyznaniowych do państwowego systemu prawnego ${ }^{6}$. Zgodnie $\mathrm{z}$ tą teorią normy prawa kanonicznego obowiązują na forum prawa państwowego $\mathrm{w}$ takim zakresie, w jakim prawodawca państwowy uznał prawomocnym aktem ich moc obowiązującą. A takim właśnie prawomocnym aktem jest m.in. międzynarodowa umowa konkordatowa między Państwem a Stolicą Apostolską.

${ }^{3}$ B. Trzeciak, Relacje Państwo-Kościót: konkordat '93-'98, Warszawa: Kontrast 1998, s. 48; P. SoвCZYк, „Każdy przecinek $w$ tym konkordacie jest zrobiony za moja osobista zgoda” - Kilka uwag na temat wplywu papieża Piusa XI na treść konkordatu polskiego z 1925 roku, „Prawo Kanoniczne" 53 (2010), nr 3-4, s. 276. Szerzej na ten temat: F.M. CAPELlo, Summa iuris publici ecclesiastici, Romae: Pontificia Universitas Gregoriana 1943, N. 261-267, s. 245- 249; A. OtTAVIANI, Institutiones iuris publici ecclesiastici, t. II: Ecclesia et status, Vaticani: Typis Polyglottis Vaticanis 1960, N. 381-383, s. 281-286.

${ }^{4}$ R. Sobański, Prawo kanoniczne a krajowy porządek prawny, „Państwo i Prawo” 6 (1999), s. 14.

${ }^{5}$ Konkordat między Stolicą Apostolską i Rzecząpospolitą Polską, podpisany w Warszawie dnia 28 lipca 1993 r., Dz. U. z 1998 r. Nr 51, poz. 318.

${ }^{6} \mathrm{Na}$ temat teorii recepcji prawa zob. P. KroczeK, Prawo wewnętrzne zwiazków wyznaniowych w perspektywie organów władzy publicznej. Klauzule generalne, Kraków: Wydawnictwo Naukowe UPJPII 2017, s. 158-160. Na temat recepcji prawa zob. A. TuniA, Recepcja prawa wewnętrznego związków wyznaniowych w prawie polskim, Lublin: Wydawnictwo KUL 2015; R. SoBAŃsKi, Recepcja prawa w Kościele, „Prawo Kanoniczne” 46 (2003), nr 3-4, s. 3-14; L. ÔRsY, The Reception of Laws by the People of God: a Theological and Canonical Inquiry in the Light of Vatican Council II, „The Jurist” 55 (1995), s. 504-526. 


\section{ZASADA NIEZALEŻNOŚCI I AUTONOMII PAŃSTWA I KOŚCIOŁA KATOLICKIEGO}

Zgodnie z art. 25 ust. 3 Konstytucji Rzeczypospolitej Polskiej z dnia 2 kwietnia 1997 r. „Stosunki między państwem a kościołami i innymi związkami wyznaniowymi są kształtowane na zasadach poszanowania ich autonomii oraz wzajemnej niezależności każdego w swoim zakresie"7. Zasada autonomii, gwarantowana w ustawie zasadniczej, potwierdzona została w art. 1 Konkordatu z 28 lipca 1993 r., w którym to stwierdza się: „Rzeczypospolita Polska i Stolica Apostolska potwierdzają, że Państwo i Kościół Katolicki są - każde w swej dziedzinie - niezależne i autonomiczne oraz zobowiązują się do pełnego poszanowania tej zasady we wzajemnych stosunkach i we współdziałaniu dla dobra człowieka i dobra wspólnego".

Autonomia Państwa i Kościoła oznacza m.in. uznanie przez obie strony prawa każdej z nich do samodzielnego tworzenia własnego systemu prawa oraz rządzenia się nim w swoim porządku ${ }^{8}$. Nie oznacza natomiast obowiązywalności prawa kanonicznego w porządku państwowym, ani też obowiązywalności prawa polskiego w porządku kościelnym ${ }^{9}$. Należy więc przyjąć, że działania podejmowane przez władze kościelne na podstawie prawa kanonicznego same z siebie nie mogą spowodować zaistnienia skutków w porządku państwowym, ani też działania władz państwowych nie mogą rodzić skutków prawnych na forum kanonicznym. „Zasada niezależności Państwa i Kościoła w swoich dziedzinach w praktyce oznacza, że władza kościelna jest całkowicie niekompetentna do ingerowania w sprawy wewnętrzne Państwa, z kolei władza państwowa jest całkowicie niekompetentna do ingerowania w sprawy wewnętrzne Kościoła"10.

\footnotetext{
${ }^{7}$ Konstytucja Rzeczypospolitej Polskiej z dnia 2 kwietnia 1997 r., Dz. U. Nr 78, poz. 483 z późn. zm.

${ }^{8}$ W odniesieniu do Kościoła katolickiego w Polsce, pisze J. Kukowski, gwarantowana w konstytucji i potwierdzona $\mathrm{w}$ Konkordacie zasada autonomii umożliwia mu rządzenie się prawem kanonicznym jak własnym prawem statutowym. W związku z powyższym, dokonanie przez kanoniczną osobę prawną czynności regulowanej prawem kanonicznym niezgodnie z przepisami tego prawa i opatrzonej w nim sankcją nieważności, skutkuje nieważnością tej czynności także w obrocie prawa państwowego z powodu nieprzestrzegania prawa statutowego. J. KruKowski, Polskie prawo wyznaniowe, Warszawa: LexisNexis 2005, s. 59.

${ }^{9}$ W. Góralski, A. PieńdyK, Zasada niezależności i autonomii państwa i Kościoła w konkordacie polskim z 1993 roku, Warszawa: Wydawnictwo Naukowe UKSW 2000, s. 16.

${ }^{10}$ P. BoReCKI, Respektowanie polskiego konkordatu z 1993 - wybrane problemy, Warszawa: Instytut Spraw Publicznych 2012, s. 11; zob. także W. Góralski, W. AdAMcZewski, Konkordat między Rzeczpospolita Polska a Stolica Apostolska z 28 lipca 1994 r., Płock: Płockie Wydawnictwo Diecezjalne 1994, s. 25.
} 


\section{WOLNOŚĆ RELIGIJNA JAKO PODSTAWA RELACJI PAŃSTWO-KOŚCIÓŁ}

Podstawą wzajemnych relacji Państwa i Kościoła Katolickiego, dwóch podmiotów wzajemnie niezależnych i autonomicznych, jest wolność religijna. To ona jest również podstawą relacji pomiędzy prawem polskim i kanonicznym; relacji, którą. R. Sobański ujął w następujący sposób: „Kościół ma obowiązek respektować prawo obowiązujące w państwie, które z kolei ma respektować jego wolność działania zgodnie z jego samoświadomością"11. Samoświadomość ta dotyczy przede wszystkim wspomnianej już wyżej misji Kościoła. W niej zaś zawiera się cel istnienia tegoż Kościoła i podejmowanych przez niego działań. Dlatego w cytowanym już art. 5 Konkordatu stwierdza się: „Przestrzegając prawa do wolności religijnej, Państwo zapewnia Kościołowi Katolickiemu, bez względu na obrządek, swobodne i publiczne pełnienie jego misji, łącznie z wykonywaniem jurysdykcji oraz zarządzaniem i administrowaniem jego sprawami na podstawie prawa kanonicznego".

Respektowanie wspomnianej wolności w ramach Państwa neutralnego religijnie oznacza, że nie uznaje ono żadnych przekonań religijnych za swoje. W kwestiach religijnych samo uznaje się ono za neutralne, a jako takie - za niekompetentne ${ }^{12}$. Neutralność religijna Państwa nie oznacza jednak neutralności jego obywateli ${ }^{13}$. Nie identyfikując się bowiem z żadną religią, Państwo świeckie, w ramach gwarantowanej ustawowo wolności religijnej, uznaje prawo osób przebywających na jego terytorium do posiadania i praktykowania rzeczonych przekonań. Polska ustawa zasadnicza z 2 kwietnia 1997 r. w art. 25 ust. 2 ujmuje to w następujący sposób: „Władze publiczne Rzeczypospolitej Polskiej zachowują bezstronność w sprawach przekonań religijnych [...] zapewniając swobodę ich wyrażania w życiu publicznym".

W nawiązaniu do powyższego, wolność religijna - w wymiarze wspólnotowym - implikuje wolność działania wspólnot religijnych zgodnie z ich samoświadomością i misją. Wspólnoty te - zgodnie z ową samoświadomością i misją dotyczącą religijnej płaszczyzny życia - kształtują własną tożsamość, wewnętrzną organizację,

\footnotetext{
${ }^{11}$ Sobański, Prawo kanoniczne, s. 8.

12 Tamże, s. 6; Pietrzak, Prawo kanoniczne, s. 17-18.

${ }^{13}$ R.M. SAtorras Fioretti, Aconfesionalidad del Estado y Cooperación con las confesiones religiosas (Art. 16.3 CE), Barcelona: Cedecs 2001, s. 66-70. W czasie tzw. II Jornadas na Papieskim Uniwersytecie Comillas w Madrycie (27 stycznia 1978 r.), Sánchez Agesta podkreślał: „Państwo nie ma religii. Religię mają ludzie organizujący się w państwo. Państwo jest instytucją świecką o określonych celach i przekracza te cele, jeśli usiłuje kierować aktami religijnymi lub ich zabraniać". Fragment wykładu pt. Polityczna perspektywa relacji państwo-Kościót, cyt. za: J. INFIESTA, El Estado ha de ser laico, „La Vanguardia” (de 28 de enero de 1978), s. 22.
} 
precyzują zadania, co znajduje wyraz w tworzonym przez nich prawie. Jako takie, w właściwym im zakresie są autonomiczne i niezależne. Uznanie tych uprawnień należy do powszechnie przyjętych dziś standardów wolności religijnej ${ }^{14}$.

Wolność religijna w wymiarze indywidualnym - jeśli mamy na myśli osobę należącą do konkretnej wspólnoty religijnej - zakłada z kolei możliwość stosowania się przez nią do zasad wynikających z religijnej doktryny tej wspólnoty oraz do praktyk religijnych, właściwych konkretnej wspólnocie wyznaniowej ${ }^{15}$. Ważną częścią owych praktyk w Kościele katolickim jest korzystanie z sakramentów. O możliwości zaś przystępowania do nich przez osoby pozostające w małżeństwie, którego ważność poddana została osądowi trybunału kościelnego, decyduje prawomocny wyrok tegoż trybunału.

\section{NIEZALEŻNOŚĆ I AUTONOMIA PAŃSTWA I KOŚCIOŁA W ZAKRESIE WŁADZY SĄDOWNICZEJ}

Skuteczność kanonicznego prawa procesowego na gruncie prawa polskiego ogranicza się do spraw wewnętrznych, właściwych temu Kościołowi (można stwierdzić, że są to sprawy natury religijnej lub z nimi związane). Niemożliwe jest odwołanie się od decyzji i orzeczeń trybunałów kościelnych do organów państwowych ani ich egzekucja przy użyciu środków przymusu państwowego. Organy państwa, także te sądowe, nie są uprawnione do kontrolowania przestrzegania prawa kanonicznego $\mathrm{w}$ procesie jego aplikacji w trybunałach kościelnych. We wzajemnych relacjach między prawem państwowym i prawem kanonicznym, w tym także między sądami obu systemów prawnych, obowiązuje generalna zasada niezależności i nieskuteczności ${ }^{16}$.

Konsekwencją uznania zasady niezależności i autonomii państwa i Kościoła, a tym samym wzajemnego respektowania odrębnych systemów prawnych w zakresie uznanym przez obie strony, są gwarancje zawarte w art. 10 Konkordatu. $\mathrm{W}$ artykule tym orzekanie w sprawach małżeństwa kanonicznego pozostawione jest sądowej jurysdykcji kościelnej i analogicznie, orzekanie w zakresie skutków cywilnych małżeństw konkordatowych - jurysdykcji państwa ${ }^{17}$. W praktyce oznacza to, że wyrok sądu cywilnego orzekającego rozwód nie rodzi żadnych skutków

\footnotetext{
${ }^{14}$ Sobański, Prawo kanoniczne, s. 7-8.

${ }^{15}$ A. Mezglewski, H. Misztal. P. Stanisz, Prawo wyznaniowe, Warszawa: C.H. Beck 2008, s. 89.

${ }^{16}$ Pietrzak, Prawo kanoniczne, s. 21.

${ }^{17}$ Artykuł 10 ust. 3 umowy konkordatowej stanowi: „Orzekanie o ważności małżeństwa kanonicznego, a także $\mathrm{w}$ innych sprawach małżeńskich przewidzianych w prawie kanonicznym, należy do wyłącznej kompetencji władzy kościelnej”. Z kolei ust. 4 tego artykułu stwierdza: „Orzekanie
} 
prawnych na forum prawa kanonicznego, a orzeczenie nieważności małżeństwa przez trybunał Kościoła Katolickiego nie wpływa na cywilny „status” konkretnego związku. Oddzielenie od siebie tych dwóch odrębnych porządków prawnych zauważa W. Góralski - ze względu na istniejące między nimi różnice wydaje się rozwiązaniem optymalnym ${ }^{18}$.

Ze wspomnianych różnic pomiędzy tymi dwoma porządkami prawnymi (w tym różnicy między instytucją rozwodu i nieważności małżeństwa kanonicznego), wynika nie tylko niekompatybilność orzeczeń sądowych wydawanych w sprawach małżeńskich w porządku prawa państwowego i kanonicznego, ale także procesów dochodzenia do tych orzeczeń. Chodzi tutaj o odmienny charakter samego procesu (cywilnego i kanonicznego) w tak podstawowych kwestiach jak: cel postępowania procesowego, tryb procedowania, zakres materiału dowodowego niezbędnego do wydania wyroku.

\section{SPECYFIKA PROCESU O NIEWAŻNOŚĆ MAŁŻEŃSTWA KANONICZNEGO}

Pisząc o kanonicznym procesie małżeńskim należy wskazać, iż stanowi on integralną część religijnej misji Kościoła. W nauce kościelnego prawa publicznego podkreślano, że Kośció - już poprzez cel swojego istnienia i działania (salus animarum) - zwrócony jest ku nadprzyrodzoności. Na religijny charakter instytucji Kościoła wskazują środki, którymi dysponuje w wypełnianiu swojej misji. Tymi środkami, zmierzającymi do uświęcenia i ostatecznie do zbawienia poszczególnych osób i wspólnot ludzkich, są sakramenty ${ }^{19}$.

Do religijnego charakteru kanonicznych procesów małżeńskich nawiązują wyraźnie przepisy dotyczące kompetencji trybunałów kościelnych. W kan. 1401 KPK/83 stwierdza się: „Mocą własnego i wyłącznego prawa Kościół rozpoznaje sprawy dotyczące rzeczy duchowych i związanych z duchowymi"20. W kan.

w sprawach małżeńskich w zakresie skutków określonych w prawie polskim należy do wyłącznej kompetencji sądów państwowych".

${ }^{18}$ Góralski, PieŃdYK, Zasada niezależności, s. 69.

${ }^{19}$ Współczesna kanonistyka - zauważa R. Sobański - dostrzega bezpośrednie powiązanie prawa kanonicznego ze zbawieniem człowieka. Można nawet stwierdzić, iż próby wyjaśnienia powiązań między prawem kanonicznym a nadprzyrodzoną płaszczyzną życia Kościoła i poszczególnych wiernych stały się jednym z głównych przedmiotów zainteresowania teoretyków prawa kanonicznego w drugiej połowie XX stulecia. Zob. R. SobaŃsKi, Kościót jako podmiot prawa, Warszawa: Akademia Teologii Katolickiej 1983, s. 98 n.

${ }^{20}$ Codex Iuris Canonici auctoritate Ioannis Pauli PP. II promulgatus (25.01.1983), AAS 75 (1983), pars II, s. 1-317; tekst polski: Kodeks Prawa kanonicznego, przekład polski zatwierdzony 
$1671 \mathrm{KPK} / 83$ stwierdza się: „Sprawy małżeńskie ochrzczonych należą, z prawa własnego, do sędziego kościelnego”, a w kan. 1672: „Sprawy dotyczące czysto cywilnych skutków małżeństwa należą do sądu cywilnego". Dwa ostatnie przepisy kodeksowe dosłownie przytacza art. 3 instrukcji procesowej Dignitas connubii ${ }^{21}$. Kodeksową zasadę rozdziału kompetencji uznaje także cytowany już tutaj art. 10 umowy konkordatowej.

Małżeństwo kanoniczne i kanoniczny proces zmierzający do stwierdzenia ważności lub nieważności tego związku, niewątpliwie należy do kategorii „rzeczy duchowych i związanych z duchowymi". Prawomocny wyrok, wydany w imieniu Kościoła, poprzez stwierdzenie ważności lub nieważności związku małżeńskiego determinuje bowiem zakres możliwości uczestniczenia stron procesowych w życiu sakramentalnym Kościoła. W ten sposób władza sądzenia w Kościele staje się jednym z elementów jego religijnej misji, a cel istnienia i działania Kościoła - salus animarum $^{22}$ - realizuje się $\mathrm{w}$ działalności jego trybunałów.

Specyfika i cel kanonicznego procesu małżeńskiego ${ }^{23}$, który wpisuje się w religijną misję Kościoła, decyduje także o specyfice samego postępowania procesowego, w tym o zakresie i charakterze materiału dowodowego niezbędnego do stwierdzenia ważności lub nieważności małżeństwa kanonicznego. Osoby uczestniczące w procesie, dostarczają sądowi materiał dowodowy, który w ich ocenie jest istotny dla tego rodzaju procesu. Czynią to z pobudek religijnych i w przekonaniu, że zostanie on wykorzystany na forum kanonicznym i w celach właściwych małżeńskiemu procesowi kanonicznemu. Dlatego też treść twierdzeń zawartych w pismach procesowych, zeznaniach dotyczy w dużej mierze spraw natury religijnej, moralnej, nieraz bardzo osobistej.

przez Konferencję Episkopatu, Poznań: Pallottinum 1984 [dalej cyt.: KPK/83].

${ }^{21}$ Pontificium Consilium de Legum Textibus, Dignitas connubii. Instructio servanda a tribunalibus dioecesanis et interdioecesanis in pertractantibus causis nullitatis matrimonii (25.01.2005), Città del Vaticano: Libreria Editrice Vaticana 2005; tekst polski: Komentarz do Instrukcji procesowej „Dignitas connubii”, red. T. Rozkrut, Sandomierz: Wydawnictwo Diecezjalne i Drukarnia w Sandomierzu 2007 [dalej cyt.: DC].

22 Zob. P. Pellegrini, La salus animarum, „Ius Canonicum” 44 (2004), nr 87, s. 141-151; P. Moneta, La "Salus animarum” sul dibattito della scienza giuridica, „Ius Ecclesiae” 12 (2000), nr 2, s. 307-326.

${ }^{23}$ T. Rozkrut stwierdza, że celem kanonicznego procesu o nieważność małżeństwa jest dojście do prawdy o ważności/nieważności konkretnego związku małżeńskiego. T. RozKRUT, Kanoniczny proces o nieważność matżeństwa: proces sporny czy proces specjalny?, „Prawo Kanoniczne” 53 (2010), nr 3-4, s. 175. 


\section{AUTONOMIA TRYBUNAŁU KOŚCIELNEGO A TAJEMNICA W PROCESIE O NIEWAŻNOŚĆ MAŁŻEŃSTWA KANONICZNEGO}

Biorąc pod uwagę wspomnianą wyżej specyfikę rzeczonego procesu i charakter gromadzonego materiału dowodowego, należy wskazać na konieczność uwrażliwiania osób uczestniczących w procesie na potrzebę zachowania tajemnicy w powyższym zakresie. Chodzi bowiem zarówno o dobro osób, których rzeczone informacje dotyczą, jak i o autonomię trybunałów kościelnych w zakresie postępowania procesowego właściwego temu trybunałowi.

Strony (i świadkowie) z jednej strony przekazują sądowi informacje - z ich punktu widzenia - ważne dla wydania właściwego wyroku, z drugiej zaś werbalizują posiadaną wiedzę i własne postrzeganie znanych im faktów w sposób trudny niejednokrotnie do przyjęcia dla drugiej strony procesu. Wynikające $\mathrm{z}$ tego trudności - ze względu na autonomię trybunału kościelnego i na dobro osób - powinny być rozstrzygane na forum konkretnego trybunału kościelnego. Tę autonomię trybunałów kościelnych - nie tylko w zakresie rozstrzygania ważności małżeństw, ale także różnego rodzaju kwestii wynikłych w trakcie rzeczonego procesu i z tym procesem związanych - powinny chronić nie tylko normy zawarte w ustawie zasadniczej i w Konkordacie, ale także tajemnica, jaką objęci są pracownicy sądu, a w poszczególnych przypadkach także biegli sądowi, strony, ich adwokaci lub pełnomocnicy ${ }^{24}$.

${ }^{24}$ Strony procesowe powinny zdawać sobie sprawę, że przedmiotem procesu kanonicznego o nieważność małżeństwa nie jest wykazanie jednej ze stron winy za rozpad ich związku. Każda strona ma prawo zwerbalizować przed sądem swoją wersję wydarzeń i związane z nimi opinie. Druga strona ma z kolei prawo zapoznać się treściami przedstawionymi sądowi przez stronę przeciwną, a po zapoznaniu może się z nimi nie zgadzać. Ta niezgodność w opisie zdarzeń i ich interpretacji występuje niejednokrotnie już na poziomie skargi procesowej, redagowanej przez stronę powodową. Brak zgody co do treści zawartych w takiej skardze skłania nieraz stronę pozwaną do przedstawienia sądowi własnej wersji zdarzeń oraz ich interpretację. Należy jednak pamiętać, że treść rzeczonej skargi jest udostępniania stronie pozwanej wyłącznie w celach związanych z procesem kanonicznym, w związku z czym treść ta nie powinna być wykorzystana przez wspomnianą stronę w celach z tym procesem nie związanych. Działania takie mogłyby prowadzić do oceniania treści zawartych w skardze powodowej przez podmioty zewnętrzne w stosunku do trybunału kościelnego (oceniania z punktu widzenia właściwego tym podmiotom) i ewentualnych żądań skierowanych do autora skargi, mających na celu nakłonienie go do zmiany treści zawartych w rzeczonym piśmie przedprocesowym. Taka zaś sytuacja mogłaby stanowić zagrożenie dla autonomii trybunału kościelnego, nie tylko w zakresie dokonywanej przez tenże sąd instrukcji procesowej, ale także w odniesieniu do treści wyroku kanonicznego, który opiera się przecież na zebranym wcześniej materiale dowodowym. 


\subsection{TAJEMNICA W PRAWIE KANONICZNYM}

Ze względu na wspomniany wyżej, specyficzny charakter informacji przekazywanych trybunałom kościelnym w procesach o nieważność małżeństwa kanonicznego i chęć ochrony osób, których te informacje dotyczą, w kan. 1470 § 1 KPK/83 ogranicza się ilość osób biorących udział w każdej, konkretnej fazie postępowania procesowego do tych, które „ustawa lub sędzia uznają za koniecznych do prowadzenia procesu"25. Dla przykładu, w czasie przesłuchania będą to tylko te osoby, bez których złożenie zeznań byłoby niemożliwe. Ponadto, w celu ochrony informacji prawodawca nakłada na osoby, których obecność jest „konieczna do prowadzenia procesu" obowiązek zachowania tajemnicy. Zakres tej tajemnicy reguluje kan. 1455 KPK/83, a za nim art. 73 DC. W artykule tym prawodawca stwierdza:

„§ 1. Sędziowie i inni urzędnicy oraz współpracownicy sądu zobowiązani są do zachowania tajemnicy urzędowej (por. kan. $1455 \S 1$ ).

$\S 2$. Sędziowie szczególnie są zobowiązani do zachowania tajemnicy dotyczącej dyskusji, która ma pośród nich miejsce w trybunale kolegialnym przed wydaniem wyroku, a także przedstawionych podczas niej różnych głosów i opinii, z zachowaniem art. $248 \S 4$ (por. kan. $1455 \S 2$ ).

$\S 3$. Ilekroć charakter sprawy lub dowodów jest taki, że rozpowszechnienie akt lub dowodów zagrażałoby sławie innych albo mogłoby być przyczyną nieporozumień lub zgorszenia, lub innych podobnych niedogodności, sędzia może zobowiązać świadków, biegłych, strony i ich adwokatów lub pełnomocników do zachowania tajemnicy specjalną przysięgą albo, jeśli wymaga tego przypadek, co najmniej przyrzeczeniem, z zachowaniem art. 159, 229-230 (por. kan. $1455 \S 3$ )".

Cytowany artykuł instrukcji procesowej wydaje się być wystarczającym zabezpieczeniem przed niebezpieczeństwem utraty dobrego imienia, „,nieporozumieniami, zgorszeniem lub inną niedogodnością", pod warunkiem, że sędzia właściwie rozezna konieczność nałożenia wspomnianego w art. 73 § 3 instrukcji zobowiązania, a osoby, których rzeczone zobowiązanie będzie dotyczyć, zachowają tajemnicę, o której mowa w cytowanym artykule ${ }^{26}$.

${ }^{25}$ Zob. także art. 86 DC.

${ }^{26} \mathrm{Na}$ temat tajemnicy chroniącej prawa do poszanowania własnej prywatności, a pośrednio prawa do ochrony dobrego imienia w prawie kanonicznym zob. P. MAJER, Ochrona prywatności w kanonicznym porządku prawnym, [w:] Ochrona danych osobowych i prawo do prywatności w Kościele, red. P. Majer, Kraków: Wydawnictwo Naukowe Papieskiej Akademii Teologicznej 2001, s. 67-98. Na temat ochrony danych osobowych w kanonicznym procesie małżeńskim zob. P. RyGuŁA, Ochrona danych osobowych w procesie o nieważność malżeństwa kanonicznego w sadach Kościoła katolickiego w Polsce, [w:] Internet. Przetwarzanie danych osobowych. Processing of personal data, red. G. Szpor, K. Czaplicki, Warszawa: C.H. Beck 2019, s. 165-174. Zob. także: J. KrzYwkowskA, Prawo do prywatności w procesie o nieważność malzeństwa, [w:] Prawo do prywatności w Koś- 


\subsection{TAJEMNICA W PRAWIE PAŃSTWOWYM}

Obowiązek zachowania tajemnicy dotyczącej informacji uzyskanych w czasie wykonywania posługi religijnej wpisany jest nie tylko w wielowiekową tradycję Kościoła. Tajemnica dotycząca tego typu informacji, w tradycji prawnej Zachodu była i nadal jest chroniona także na forum pozakanonicznym. Zakres tej ochrony jest jednak różny w różnych systemach prawa państwowego.

Można wspomnieć tutaj m.in. o tajemnicy spowiedzi, chronionej również i dzisiaj na gruncie prawa polskiego. W prawie kanonicznym tajemnica ta dotyczy nie tylko spowiednika, ale także tłumacza (jeśli występuje), a także innych osób, które „w jakikolwiek sposób zdobyły ze spowiedzi wiadomości o grzechach” (KPK/83, kan. $983 \S 2$ ). Na gruncie prawa polskiego obowiązek zachowania tajemnicy spowiedzi znajduje swoje uzasadnienie w konstytucyjnie gwarantowanym prawie do praktykowania religii ${ }^{27}$. Zakaz przesłuchiwania duchownego co do faktów, o których dowiedział się w czasie spowiedzi, ujęty jest w kategorii bezwzględnych zakazów dowodowych, przewidzianych w postępowaniu karnym (zob. art. 178 pkt 2 k.p.k.) ${ }^{28}$ i w procedurze administracyjnej (zob. art. 82 pkt 3 k.p.a.) ${ }^{29}$. W procedurze postępowania cywilnego zachowanie wspomnianej tajemnicy zabezpieczone jest prawem spowiednika do odmowy zeznań dotyczących informacji uzyskanych w trakcie sprawowania wspomnianej posługi religijnej (zob. art. $261 \S 2$ k.p.c.) ${ }^{30}$.

W wielu systemach praw państwowych obowiązek zachowania tajemnicy obejmuje szerszy zakresu religijnego życia ludzkiego niż tylko sama spowiedź. Dla przykładu, hiszpańska umowa konkordatowa z 1976 r., w art. 2 ust. 3 stwierdza: „W żadnym wypadku duchowni i osoby zakonne nie będą mogli być wzywani przez sędziów lub innych przedstawicieli władzy państwowej, w celu udzielenia informacji co do osób lub materii, o których wiedzę nabyli ze względu na pełnioną przez nich posługę"31. Zapisy tej treści zawarte zostały także w art. 3 wszystkich trzech umów z 1992 r., zawartych między państwem hiszpańskim a wyznaniami

ciołach $i$ innych zwiazkach wyznaniowych, red. T.J. Zieliński, M. Hucał, Warszawa: Wydawnictwo Naukowe ChAT 2019, s. 339-354. W szerszej perspektywie zob. także: B. ŁuKAŃKo, Kościelne modele ochrony danych osobowych, Warszawa: Wolters Kluwer 2019.

${ }^{27}$ Mezglewski, Misztal, Stanisz, Prawo wyznaniowe, s. 262.

${ }^{28}$ Ustawa z dnia 6 czerwca 1997 r. Kodeks postępowania karnego, Dz. U. Nr 89, poz. 555.

${ }^{29}$ Ustawa z dnia 14 czerwca 1960 r. Kodeks postępowania administracyjnego, Dz. U. Nr 30, poz. 168.

${ }^{30}$ Ustawa z dnia 17 listopada 1964 r. Kodeks postępowania cywilnego, Dz. U. Nr 43, poz. 296.

${ }^{31}$ Acuerdo entre la Santa Sede y el Estado español, BOE 1976, n. ${ }^{\circ} 230$ (de 24 de septiembre), s. 18664-18665 (tłumaczenia z hiszpańskiego w niniejszym artykule są thumaczeniami autora artykułu). 
niekatolickimi ${ }^{32}$. Hiszpańska Ustawa o postępowaniu karnym ${ }^{33}$, stanowiąc $\mathrm{w}$ art. 262 obowiązek powiadamiania właściwych organów państwa o popełnieniu przestępstwa, w art. 263 wyłącza $\mathrm{z}$ tego obowiązku m.in. „duchownych i ministrów innych wyznań odnośnie do tych spraw, o których dowiedzieli się w czasie pełnienia swojej posługi”. W art. 417 ustawa ta stwierdza ponadto: „Nie będą obligowani do składania zeznania jako świadkowie [...] duchowni oraz ministrowie innych wyznań na temat faktów wyjawionych im w czasie pełnienia funkcji związanych z ich posługą"34. Tajemnicą (określaną jako secreto ministerial) w rzeczonym systemie prawa państwowego objęte są więc z zasady nie tylko treści wyjawione duchownemu w czasie spowiedzi. Nie tylko bowiem w trakcie spowiedzi, ale także w czasie innych posług o charakterze religijnym osobom, które te czynności wypełniają, ujawniane są (ze względów religijnych) informacje dotyczące prywatnej sfery życia człowieka.

Także w trakcie kanonicznego procesu małżeńskiego podawane tam informacje dotyczą niejednokrotnie prywatnego zakresu życia osób biorących w tym procesie udział. Dlatego też tajemnica urzędowa, służąca zachowaniu informacji uzyskanych w trakcie procesu do wyłącznego, wewnętrznego użytku trybunału kościelnego, ma fundamentalne znaczenie dla tych, którzy pragną korzystać z prawa do praktyk religijnych, a ze względu na swoją sytuację życiową pozostają w stanie uzasadnionej wątpliwości co do ważności swojego małżeństwa sakramentalnego. Pewność co do zachowania rzeczonej tajemnicy umożliwia wspomnianym osobom szczere formułowanie twierdzeń, które uznają one za istotne dla toczącego się procesu. Sytuacja przeciwna natomiast ogranicza tym osobom wspomnianą możliwość, a co za tym idzie, ogranicza także trybunałom kościelnym uzyskanie pełnego materiału dowodowego ${ }^{35}$.

${ }^{32}$ Ley 24/1992, de 10 de noviembre, por la que se aprueba el Acuerdo de Cooperación del Estado con la Federación de Entidades Religiosas Evangélicas de España, BOE 1992, n. ${ }^{\circ} 272$ (de 12 de noviembre), s. 38209-38211; Ley 25/1992, de 10 de noviembre, por la que se aprueba el Acuerdo de Cooperación del Estado con la Federación de Comunidades Israelitas de España, BOE 1992, n. ${ }^{\circ}$ 272 (de 12 de noviembre), s. 38211-38214; Ley 26/1992, de 10 de noviembre, por la que se aprueba el Acuerdo de Cooperación del Estado con la Comisión Islámica de España, BOE 1992, n. ${ }^{\circ} 272$ (de 12 de noviembre), s. 38214-38217.

${ }^{33}$ Ley de Enjuiciamiento Criminal, BOE núm. 260, de 17/09/1882.

${ }^{34}$ P. Rygula, Wolność religijna $w$ Hiszpanii na tle przemian spoleczno-politycznych $w$ latach 1931-1992, Katowice: Wydawnictwo Naukowe UŚ 2009, s. 360.

${ }^{35}$ Tajemnica dotycząca kanonicznych procesów małżeńskich nie jest chroniona na gruncie prawa polskiego tak, jak ma to miejsce w przypadku tajemnicy spowiedzi. Informacje zawarte w materiale dowodowym takiego procesu chronione są więc w Polsce przepisami prawa kanonicznego, uznanymi w umowie konkordatowej (art. 10 ust. 3 konkordatu z 1993 r.) za właściwe w tym przypadku. Prawo kanoniczne nakłada na trybunały kościelne obowiązek zachowania tajemnicy urzędowej (kan. $1455 \S$ 


\subsection{ZACHOWANIE TAJEMNICY PRZEZ STRONĘ PROCESOWĄ}

Skoro nie wszystkie systemy prawa państwowego chronią tzw. tajemnicę duszpasterską, ograniczając się wyłącznie do ochrony tajemnicy spowiedzi, tym bardziej istotną kwestią staje się zachowanie tajemnicy przez strony procesowe ${ }^{36}$. Trybunałom kościelnym znane są przypadki, w których strony te wyrażają dezaprobatę co do treści, jakie znalazły się w zbieranym przez trybunał materiale dowodowym, uznając je za nieprawdziwe co do faktów lub krzywdzące co do interpretacji. Strony te należy wówczas uwrażliwić na specyfikę procesu kanonicznego, zmierzającego do dojścia do prawdy o kanonicznej ważności lub nieważności małżeństwa ${ }^{37}$. Specyfika ta wymaga niejednokrotnie zawarcia w rzeczonym materiale wrażliwych dla stron informacji oraz ich interpretacji z punktu widzenia poszczególnych uczestników procesu ${ }^{38}$.

Będąc świadome co do możliwości wyrażenia przez strony w niektórych wypadkach dezaprobaty odnośnie do treści zebranego materiału dowodowego, trybunały kościelne udostępniają im wspomnianą treść. Czynią to po pierwsze, aby - biorąc pod uwagę prawo do obrony (por. KPK/83, kan. 1598) - strony mogły się co do wspomnianej treści ustosunkować, po drugie - aby umożliwić w ten sposób także

1-2 KPK/83). Z tego też powodu trybunały te nie mogą udostępniać materiału dowodowego w celach nie związanych z konkretnym procesem kanonicznym, a sądy państwowe winny być tego świadome.

${ }^{36}$ Pisząc o tajemnicy zachowywanej przez stronę procesową mam na myśli sytuację, w której strona ta $\mathrm{z}$ własnej woli (nie zobowiązana przepisami) lub też pod rygorem obowiązujących przepisów nie ujawnia poza forum konkretnego sądu kościelnego treści zawartych w materiale dowodowym danego procesu o nieważność małżeństwa kanonicznego. Przepisy te - w zależności okoliczności - mogą wprost zobowiązywać stronę do zachowania tajemnicy na forum pozakanonicznym lub też regulować dostęp do materiału dowodowego (w tym do odpisów tych aktów) w taki sposób, aby nie doszło do wyjawienia przez stronę treści zawartych w aktach procesowych poza forum kanoniczne.

${ }^{37}$ Dnia 28 stycznia 2006 r. zwracając się do sędziów Roty Rzymskiej papież Benedykt XVI podkreślał, że kanoniczny proces o nieważność małżeństwa stanowi w Kościele prawny instrument, za pomocą którego dochodzi się do prawdy odnośnie do ważności lub nieważności konkretnego małżeństwa. „Dlatego też, zasadniczym celem nie jest niepotrzebne komplikowanie życia wiernych, ani tym bardziej podkreślanie spornego charakteru tego procesu, ale tylko przysłużenie się prawdzie". Cyt. za: C.M. Morán Bustos, Criterios de actuación de los miembros del tribunal y los abogados en el desarrollo del proceso de nulidad, [w:] Procesos matrimoniales canónicos, red. Asociación Española de Canonistas, Madrid: Dykinson 2014, s. 25-26.

${ }^{38}$ Można założyć, że nie tylko treść informacji dotyczących konkretnego związku małżeńskiego, ale także postrzeganie ich przez strony i świadków w procesie kanonicznym i cywilnym (ze względu na odmienny cel, do jakiego zmierzają dwa wspomniane procedowania) będą różne. Mając niejednokrotnie doświadczenie procesu rozwodowego, strony mogą być zdziwione treścią pytań stawianych im przez audytorów w czasie przesłuchania, a także treścią zeznań i pism procesowych złożonych przed sądem przez drugą stronę procesu. 
i samemu trybunałowi zobiektywizowanie zgromadzonego $\mathrm{w}$ procesie materiału dowodowego.

Biorąc pod uwagę przepisy kan. $1455 \S 1-2 \mathrm{KPK} / 83$, strony nie powinny obawiać się wyjawienia przez sędziów i innych urzędników oraz współpracowników sądu informacji zawartych w materiale dowodowym. Same jednak także powinny dostrzegać konieczność zachowania tajemnicy, nawet jeśli w konkretnym przypadku przepisy zawarte w kan. $1455 \S 3 \mathrm{KPK} / 83$ oraz z art. 73 Dignitas connubii bezpośrednio ich do tego nie zobowiązują. Zachowanie jej gwarantuje bowiem, że informacje przekazane sądowi - przy zachowaniu właściwych przepisów kanonicznych - nie zostaną wyjawione poza forum konkretnego trybunału kościelnego. Nie będąc upublicznione poza to forum, nie staną się powodem naruszenia dóbr osobistych tych, których dotyczą. Nie staną się także powodem i podstawą formułowania ocen odnośnie do materiału dowodowego zebranego na forum kanonicznym i w celu właściwym procesowi kanonicznemu według kryteriów niekanonicznych.

W związku z powyższym, instrukcja procesowa Dignitas connubii regulując sposób korzystania przez strony z materiału dowodowego w czasie publikacji akt stanowi:

„Art. $232-\S 1$. Sędzia może zobowiązać strony przed analizą akt przysięgą lub, jeśli sytuacja tego wymaga, przyrzeczeniem, aby z pozyskanej wiedzy przez taką analizę korzystały jedynie w celu wykonywania prawa do obrony na forum kanonicznym (por. $1455 \S 3$ ).

$\S 2$. Jeśli zaś strona odmawia złożenia przysięgi lub jeśli sytuacja tego wymaga, przyrzeczenia, zakłada się, że zrzekła się możliwości przejrzenia akt, chyba że prawo partykularne stanowi inaczej".

Zawarte w cytowanym artykule przepisy uniemożliwiają stronie procesowej posłużenie się na forum pozakanonicznym informacjami, które - z jej perspektywy - powodują konieczność obrony. Można powiedzieć, że wymuszają one na stronie zachowanie tajemnicy w powyższym zakresie. Przepisy te nie pozbawiają strony odmawiającej złożenia przysięgi (a w wypadku osoby niewierzącej - przyrzeczenia) prawa do rzeczonej obrony. Gwarantują to prawo jednak wyłącznie na forum kanonicznym, tj. na tym, które właściwe jest prawodawcy kościelnemu ${ }^{39}$.

Wskazując na przepisy, których celem jest uniemożliwienie wyjawienia przez strony procesowe na forum pozakanonicznym treści zawartych $\mathrm{w}$ aktach procesu kanonicznego, należy wspomnieć jeszcze art. 235 Dignitas connubii. Upoważnia on sędziego do udostępnienia odpisu akt sprawy adwokatowi strony, jeśli ten

\footnotetext{
${ }^{39}$ Niemożliwe bowiem jest - biorąc pod uwagę zasadę autonomii Państwa i Kościoła w zakresie władzy sądowniczej - aby prawodawca kościelny skutecznie mógł gwarantować to prawo na forum prawa państwowego.
} 
o to poprosi (art. $235 \S 1)^{40}$, zastrzegając równocześnie, iż - jeśli rzeczony odpis uzyska - adwokat ma poważny obowiązek nieprzekazywania go komukolwiek, nie wyłączając stron. W ten sposób - zauważa Morán Bustos ${ }^{41}$ - prawodawca kościelny pragnie uniemożliwić niewłaściwe użycie środków dowodowych będących w posiadaniu trybunału kościelnego przez strony procesowe np. na forum sądów państwowych (m.in. w procesach karnych toczonych przeciwko drugiej stronie procesu kanonicznego lub świadkowi) ${ }^{42}$.

\section{AUTONOMIA ORZEKANIA TRYBUNAŁÓW KOŚCIELNYCH W ZAKRESIE MAŁŻEŃSTW KANONICZNYCH A PRAWO DO WOLNOŚCI RELIGIJNEJ}

Zgodnie z art. 53 ust. 1 Konstytucji Rzeczypospolitej Polskiej „każdemu zapewnia się wolność sumienia i religii”. Zakres przedmiotowy gwarantowanej wolności, zgodnie z art. 53 ust. 2 ustawy zasadniczej obejmuje „wolność [...] uzewnętrzniania indywidualnie lub z innymi, publicznie lub prywatnie, swojej religii przez uprawianie kultu, modlitwę, uczestniczenie w obrzędach, praktykowanie i nauczanie". Konstytucyjne gwarancje zapewniają więc każdej osobie prawo do uczestniczenia w obrzędach i do praktyk religijnych właściwych dla Kościoła czy związku wyznaniowego, do którego się należy; w wypadku katolików cytowany przepis gwarantuje m.in. prawo do korzystania z sakramentów w sposób określony religijną doktryną Kościoła katolickiego.

Jak już wspomniano, zasadniczym celem kanonicznego procesu małżeńskiego jest stwierdzenie ważności lub nieważności małżeństwa stron procesowych. Wyrok sądu kościelnego w powyższej sprawie, niosąc z sobą stwierdzenie stanu faktycznego co do pozostawania stron procesowych w ważnym związku kanonicznym lub w stanie wolnym, determinuje zakres możliwości uczestniczenia przez każdą

\footnotetext{
${ }^{40}$ Udostępnienie odpisu akt procesowych nie jest obowiązkiem sędziego i zależy od praktyki danego sądu i oceny dokonanej dla konkretnego przypadku.

${ }^{41}$ Carlos Manuel Morán Bustos jest dziekanem Trybunału Roty Nuncjatury Apostolskiej w Hiszpanii (tzw. Roty Hiszpańskiej), profesorem Uniwersytetu Nawarry i Papieskiego Uniwersytetu Comillas w Madrycie.

${ }^{42}$ Morán Bustos, Criterios de actuación, s. 97. Analizując przewidziane prawem przypadki nieudostępniania stronom całości lub części materiału dowodowego należy wspomnieć jeszcze o art. 230 DC, w którym stwierdza się: „Dla uniknięcia zaś bardzo poważnych niebezpieczeństw sędzia może zadecydować, że jakiegoś aktu nie należy ujawniać stronom, gwarantując jednak, że prawo do obrony pozostaje zawsze nienaruszone". Analiza tego przepisu zob.: E. de León Rey, Publicación de las actas, privacidad de los hechos y prueba secreta (can. 1598 \& 1 CIC 83 / art. 230 DC), [w:] Procesos matrimoniales, s. 157-171.
} 
z tych stron w życiu sakramentalnym Kościoła katolickiego. W rzeczywistości skutki prawne wyroku kanonicznego sięgają więc dalej niż tylko sama możliwość zawarcia związku kanonicznego przez strony procesu z osobą trzecią (lub brak takiej możliwości). Dotykają także możliwości przystępowania rzeczonych stron do innych sakramentów, takich jak spowiedź czy Komunia święta. Patrząc z tej perspektywy, zachowanie autonomii sądów kanonicznych w zakresie procesów o nieważność małżeństwa jest kwestią fundamentalną, jeśli chodzi o możliwość korzystania z konstytucyjnego prawa do wolności sumienia i wyznania przez osoby pozostające pod jurysdykcją tych trybunałów.

\section{BIBLIOGRAFIA}

\section{ŹRÓDŁA PRAWA}

Acuerdo entre la Santa Sede y el Estado español, BOE 1976, n. 230 (de 24 de septiembre), s. 18664 18665.

Codex Iuris Canonici auctoritate Ioannis Pauli PP. II promulgatus (25.01.1983), AAS 75 (1983), pars II, s. 1-317; tekst polski: Kodeks Prawa kanonicznego, przekład polski zatwierdzony przez Konferencję Episkopatu, Poznań: Pallottinum 1984.

Konkordat między Stolicą Apostolską i Rzecząpospolitą Polską, podpisany w Warszawie dnia 28 lipca 1993 r., Dz. U. z 1998 r. Nr 51, poz. 318.

Konstytucja Rzeczypospolitej Polskiej z dnia 2 kwietnia 1997 r., Dz. U. Nr 78, poz. 483 z późn. zm. Ley 24/1992, de 10 de noviembre, por la que se aprueba el Acuerdo de Cooperación del Estado con la Federación de Entidades Religiosas Evangélicas de España, BOE 1992, n. ${ }^{\circ} 272$ (de 12 de noviembre), s. 38209-38211.

Ley 25/1992, de 10 de noviembre, por la que se aprueba el Acuerdo de Cooperación del Estado con

la Federación de Comunidades Israelitas de España, BOE 1992, n. 272 (de 12 de noviembre), s. $38211-38214$.

Ley 26/1992, de 10 de noviembre, por la que se aprueba el Acuerdo de Cooperación del Estado con la Comisión Islámica de España, BOE 1992, n. ${ }^{\circ} 272$ (de 12 de noviembre), s. 38214-38217.

Ley de Enjuiciamiento Criminal, BOE n. ${ }^{\circ} 260$, de 17/09/1882.

Pontificium Consilium de Legum Textibus, Dignitas connubii. Instructio servanda a tribunalibus dioecesanis et interdioecesanis in pertractantibus causis nullitatis matrimonii (25.01.2005), Città del Vaticano: Libreria Editrice Vaticana 2005; tekst polski: Komentarz do Instrukcji procesowej „Dignitas connubii”, red. T. Rozkrut, Sandomierz: Wydawnictwo Diecezjalne i Drukarnia w Sandomierzu 2007.

Ustawa z dnia 14 czerwca 1960 r. Kodeks postępowania administracyjnego, Dz. U. Nr 30, poz. 168 Ustawa z dnia 17 listopada 1964 r. Kodeks postępowania cywilnego, Dz. U. Nr 43, poz. 296.

Ustawa z dnia 6 czerwca 1997 r. Kodeks postępowania karnego, Dz. U. Nr 89, poz. 555. 


\section{LITERATURA}

Borecki Paweł: Respektowanie polskiego konkordatu z 1993 - wybrane problemy, Warszawa: Instytut Spraw Publicznych 2012.

CAPEllo Felice M.: Summa iuris publici ecclesiastici, Romae: Pontificia Universitas Gregoriana 1943.

Góralski Wojciech, AdAMczewski Witold: Konkordat między Rzeczpospolitą Polską a Stolicą Apostolską z 28 lipca 1994 r., Płock: Płockie Wydawnictwo Diecezjalne 1994.

GóRALSKI Wojciech, PIEŃDYK Andrzej: Zasada niezależności i autonomii państwa i Kościoła w konkordacie polskim z 1993 roku, Warszawa: Wydawnictwo Naukowe UKSW 2000.

INFIESTA Jesús: El Estado ha de ser laico, La Vanguardia (de 28 de enero de 1978), s. 22.

Kroczek Piotr: Prawo wewnętrzne związków wyznaniowych w perspektywie organów władzy publicznej. Klauzule generalne, Kraków: Wydawnictwo Naukowe UPJPII 2017.

KRUKOwski Józef: Polskie prawo wyznaniowe, Warszawa: LexisNexis 2005.

Krzywkowska Justyna: Prawo do prywatności w procesie o nieważność małżeństwa, [w:] Prawo do prywatności w Kościołach i innych związkach wyznaniowych, red. T.J. Zieliński, M. Hucał, Warszawa: Wydawnictwo Naukowe ChAT 2019, s. 339-354.

León Rey Enrique de: Publicación de las actas, privacidad de los hechos y prueba secreta (can. 1598 $\S 1$ CIC 83 / art. 230 DC), [w:] Procesos matrimoniales canónicos, red. Asociación Española de Canonistas, Madrid: Dykinson 2014, s. 157-171.

ŁUKAŃKO Bernard: Kościelne modle ochrony danych osobowych, Warszawa: Wolters Kluwer 2019. MAJER Piotr: Ochrona prywatności w kanonicznym porządku prawnym, [w:] Ochrona danych osobowych i prawo do prywatności w Kościele, red. P. Majer, Kraków: Wydawnictwo Naukowe Papieskiej Akademii Teologicznej 2001, s. 67-98.

MezGlewski Artur, Misztal Henryk, Stanisz Piotr, Prawo wyznaniowe, Warszawa: C.H. Beck 2008.

Moneta Paolo: La "Salus animarum" sul dibattito della scienza giuridica, Ius Ecclesiae 12 (2000), nr 2, s. 307-326.

Morán Bustos Carlos M.: Criterios de actuación de los miembros del tribunal y los abogados en el desarrollo del proceso de nulidad, [w:] Procesos matrimoniales canónicos, red. Asociación Española de Canonistas, Madrid: Dykinson 2014, s. 25-114.

OtTAVIANi Alfredo: Institutiones iuris publici ecclesiastici, vol. II: Ecclesia et status, Vaticani: Typis Polyglottis Vaticanis 1960.

ÔRSY Ladislas: The Reception of Laws by the People of God: a Theological and Canonical Inquiry in the Light of Vatican Council II, The Jurist 55 (1995), s. 504-526.

Pellegrini Piero: La salus animarum, Ius Canonicum 44 (2004), nr 87, s. 141-151.

PietrzaK Michał: Prawo kanoniczne w polskim systemie prawnym, Państwo i Prawo 8 (2006), s. $16-31$.

RozKrut Tomasz: Kanoniczny proces o nieważność małżeństwa: proces sporny czy proces specjalny?, Prawo Kanoniczne 53 (2010), nr 3-4, s. 172-182.

RyguŁa Piotr: Ochrona danych osobowych w procesie o nieważność małżeństwa kanonicznego w sądach Kościoła katolickiego w Polsce, w: Internet. Przetwarzanie danych osobowych. Processing of personal data, red. G. Szpor, K. Czaplicki, Warszawa: C.H. Beck 2019, s. 165-174.

RyGuŁa Piotr: Wolność religijna w Hiszpanii na tle przemian społeczno-politycznych w latach 19311992, Katowice: Wydawnictwo Naukowe UŚ 2009.

RZEPECKI Andrzej: Funkcjonowanie prawa kanonicznego w polskim porządku prawnym - zarys tematu, Acta Erasmiana 5 (2013), s. 163-184.

Satorras Fioretti Rosa M.: Aconfesionalidad del Estado y Cooperación con las confesiones religiosas (Art. 16.3 CE), Barcelona: Cedecs 2001. 
SoBAŃSKI Remigiusz: Kościół jako podmiot prawa, Warszawa: Akademia Teologii Katolickiej 1983. SobaŃski Remigiusz: Prawo kanoniczne a krajowy porządek prawny, Państwo i Prawo 6 (1999), S. 3-17.

SobaŃski Remigiusz: Recepcja prawa w Kościele, Prawo Kanoniczne 46 (2003), nr 3-4, s. 3-14.

SoBCZYK Paweł: „Każdy przecinek w tym konkordacie jest zrobiony za moja osobistą zgodą” - Kilka uwag na temat wpływu papieża Piusa XI na treść konkordatu polskiego z 1925 roku, Prawo Kanoniczne 53 (2010), nr 3-4, s. 273-288.

Trzeciak Bogusław: Relacje Państwo-Kościół: konkordat '93-'98, Warszawa: Kontrast 1998.

TUNIA Anna: Recepcja prawa wewnętrznego związków wyznaniowych w prawie polskim, Lublin:

Wydawnictwo KUL 2015.

\section{AUTONOMIA TRYBUNAŁÓW KOŚCIELNYCH W POLSCE W ORZEKANIU NIEWAŻNOŚCI MAŁŻEŃSTWA KANONICZNEGO: PRZYCZYNEK DO ANALIZY ZAGADNIENIA}

\section{Streszczenie}

Zgodnie z art. 25 ust. 3 Konstytucji Rzeczypospolitej Polskiej z dnia 2 kwietnia 1997 r. „Stosunki między państwem a kościołami i innymi związkami wyznaniowymi są kształtowane na zasadach poszanowania ich autonomii oraz wzajemnej niezależności każdego w swoim zakresie". Konsekwencją uznania zasady niezależności i autonomii państwa i Kościoła, a tym samym wzajemnego respektowania odrębnych systemów prawnych w zakresie uznanym przez obie strony, są gwarancje zawarte w art. 10 Konkordatu. W artykule tym orzekanie w sprawach małżeństwa kanonicznego pozostawione jest sądowej jurysdykcji kościelnej i analogicznie, orzekanie w zakresie skutków cywilnych małżeństw konkordatowych - jurysdykcji państwa. W praktyce oznacza to, że wyrok sądu cywilnego orzekającego rozwód nie rodzi żadnych skutków prawnych na forum prawa kanonicznego, a orzeczenie nieważności małżeństwa przez trybunał Kościoła Katolickiego nie wpływa na cywilny „status” konkretnego związku.

Dla zachowania autonomii trybunałów kościelnych niezwykle ważna jest kwestia nieingerowania podmiotów niekanonicznych $\mathrm{w}$ proces zbierania materiału dowodowego przez rzeczony trybunał oraz niewykorzystywania wspomnianego materiału na forum pozakanonicznym (np. w procesach cywilnych czy karnych toczonych w sądach państwowych). W tej kwestii niezwykle ważne jest zachowanie tajemnicy nie tylko przez pracowników sądów kościelnych, adwokatów i biegłych, ale także przez same strony procesowe. Temu zagadnieniu Autor artykułu poświęca sporo uwagi.

Wyrok sądu kościelnego determinuje zakres możliwości uczestniczenia przez każdą ze stron procesowych w życiu sakramentalnym Kościoła Katolickiego. W rzeczywistości bowiem skutki prawne wyroku kanonicznego nie dotyczą tylko możliwość zawarcia związku kanonicznego przez strony procesu z osobą trzecią (lub brak takiej możliwości). Dotykają także możliwości przystępowania rzeczonych stron do innych sakramentów, takich jak spowiedź czy Komunia święta. Patrząc $\mathrm{z}$ tej perspektywy, zachowanie autonomii sądów kanonicznych w zakresie procesów o nieważność małżeństwa jest kwestią fundamentalną, jeśli chodzi o możliwość korzystania z konstytucyjnego prawa do wolności sumienia i wyznania przez osoby pozostające pod jurysdykcją tych trybunałów.

Słowa kluczowe: nieważność małżeństwa kanonicznego; trybunał kościelny; autonomia trybunałów kościelnych; tajemnica w prawie kanonicznym 


\section{AUTONOMY OF ECCLESIASTICAL TRIBUNALS PRONOUNCING THE NULLITY OF CANONICAL MARRIAGE: A TRIGGER FOR AN ANALYSIS OF THE PROBLEM}

\section{Sum mary}

According to Article 25, Paragraph 3 of the Constitution of the Polish Republic of 2 April 1997, "the relationship between the State and churches and other religious organizations shall be based on the principle of respect for their autonomy and the mutual independence of each in its own sphere." The consequences of the principles of independence and autonomy of the State and the Church, which assume a reciprocal acceptance of independent legal systems within limits decided by both sides, are the guarantees included in Article 10 of the Concordat. In that Article, pronouncing judgments concerning canonical marriage is left to ecclesiastical jurisdiction, and, in an analogical way, pronouncing judgments concerning concordat marriage - to state jurisdiction. In practice, it means that a sentence of a civil tribunal pronouncing the divorce has no legal consequences in the sphere of canon law, while pronouncing the nullity of marriage by a Catholic tribunal does not influence the civil status of that marriage.

In order to preserve autonomy of ecclesiastical tribunals it is very important that non-ecclesiastical subjects refrain from interfering with the process of collecting evidence by an ecclesiastical tribunal and from using the gathered material outside of canonical courts (for instance, in civil cases or criminal cases in state courts). The secret ought to be kept not only by employees of ecclesiastical courts, attorneys and experts, but also by the parties in litigation. The author of this paper devotes a lot of attention to this issue.

A sentence of an ecclesiastical tribunal determines the range of possibilities of participating in the sacramental life of the Catholic Church by the parties to a case. In fact, the legal consequences of a canonical sentence refer not only to the possibility of getting married with a third party by the parties in litigation (or to the lack of this possibility). They also relate to the possibility of going to confession or receiving the Holy Communion. From this perspective, preserving autonomy of ecclesiastical tribunals in the sphere of the nullity of marriage is a fundamental issue when it comes to the constitutional freedoms of conscience and religion of persons remaining under the jurisdiction of those tribunals.

Key words: nullity of canonical marriage; ecclesiastical tribunal; autonomy of ecclesiastical tribunals; secret in canon law 